\title{
Environmental earth sciences
}

\author{
James W. LaMoreaux · Gunter Dörhöfer • \\ Olaf Kolditz
}

Received: 27 February 2015/Accepted: 1 March 2015/Published online: 24 March 2015

(C) Springer-Verlag Berlin Heidelberg 2015

This editorial is to inform the readers of the international journal of Environmental Earth Sciences of the history, progress and status of the journal, which is published by Springer Science + Business Media (Springer). Environmental Earth Sciences serves the disciplines of environmental geology, engineering geology, hydrology, hydrogeology, carbonate hydrology, karst and caves, geochemistry, geophysics, land use management, geohazards, mining impacts, mineralogy, landfill management, geomorphology, geomathematics, earthquakes and seismicity, desertification, remote sensing, geographic information systems, geostatistics, computational science, modeling, soils, radioactivity and nuclear science, sedimentology, and oceanography.

The journal was first published in 1975 as Environmental Geology for which Dr. L. Jan Turk served as Editorin-Chief (EIC) with an Editorial Board of 18 members. In 1980, Dr. Philip E. LaMoreaux, Sr., President of P.E. LaMoreaux and Associates, Inc. (PELA), was appointed as EIC and served faithfully in that capacity until his death in June 2008. At his death, Dr. James W. LaMoreaux was appointed as EIC after serving several years on the Editorial Board for the journal. Due to the increase in the

J. W. LaMoreaux ( $\square)$

P.E. LaMoreaux and Associates, Inc., Tuscaloosa, AL, USA

e-mail: eeswest@yahoo.com

G. Dörhöfer

Genthiner Str. 76, 14774 Brandenburg, a.d. Havel, Germany

e-mail: doerhoefer@gmail.com

O. Kolditz

Helmholtz-Zentrum für Umweltforschung, Environmental Informatics, Leipzig, Germany

e-mail: olaf.kolditz@ufz.de number of manuscripts received for the journal, Dr. Gunter Dörhöfer was appointed by Springer in the early 1990s as EIC for Europe after having served for several years on the Editorial Board. In 2014, Dr. Olaf Kolditz was appointed as the third EIC due to the journal's rapid expansion and for the management of its thematic issues, which are dedicated to comprehensive collections on special topics in environmental earth sciences. Dr. Kolditz had served for several years as Associate Editor for the journal.

Since its inception, there have been varied titles for the journal: Environmental Geology, Environmental Geology and Water Sciences, Environmental Geology (again). It is now titled Environmental Earth Sciences as a result of broadening the aims and scope of the journal to reach the broader sphere of environmental earth sciences. As a result of extending the aims and scope, the journal has significantly expanded, increasing the need for more assistance with the management of the journal. As of January 2015, Springer has appointed ten Associate Editors (AEs) for the journal who will assist in managing the submitted manuscripts. The present Editorial Board consists of 37 members.

In the mid-2000s, Springer implemented the online submission capability, which aided authors in a faster and easier method in which to submit a manuscript. As a result, the rate of manuscript submissions increased significantly, causing a rapid rise in the number of issues published annually. In the first few years, the journal only published two to four issues per year containing about ten manuscripts per issue. When submissions began to increase, Springer increased the number of issues per year to eight, then twelve, then eighteen and now 24 issues per year. Since the broadening of the aims and scope of the journal, the number of submissions has substantially increased each year with a monumental number of 2151 manuscripts 
submitted in 2014 and an expectation of a continued increase in the years to come. There are approximately 9000 reviewers in the online submission system, which make it possible to manage such a large number of submitted manuscripts.

Not only has the journal expanded in the abovementioned manner, but it has also broadened its horizon geographically in the dissemination of research from represented countries from which formerly very little research had been received.
Springer, the EICs, and AEs wish to express our gratitude for the success of the journal to the authors and coauthors who have tirelessly dedicated themselves to contributing results of key research and studies. Editorial Board members and many reviewers have spent countless hours providing suggestions to authors to make it possible to publish the manuscripts, which is greatly appreciated. We look forward to many years of progress and growth for the international journal of Environmental Earth Sciences. 